\title{
Effects of previous nitrogen addition on chlorine in forest soil, soil solution and biomass
}

\author{
Teresia Svensson, Lars Högbom, Karin Johansson and Eva Ring
}

\section{Linköping University Post Print}

\section{Tweet}

N.B.: When citing this work, cite the original article.

The original publication is available at www.springerlink.com:

Teresia Svensson, Lars Högbom, Karin Johansson and Eva Ring, Effects of previous nitrogen addition on chlorine in forest soil, soil solution and biomass, 2013, Biogeochemistry, (116), 13, 3-13.

http://dx.doi.org/10.1007/s10533-013-9888-3

Copyright: Springer Verlag (Germany)

http://www.springerlink.com/?MUD=MP

Postprint available at: Linköping University Electronic Press

http://urn.kb.se/resolve?urn=urn:nbn:se:liu:diva-102636 


\title{
EFFECTS OF PREVIOUS NITROGEN ADDITION ON CHLORINE IN FOREST SOIL, SOIL SOLUTION AND BIOMASS
}

\begin{abstract}
There is increasing evidence that forests and forest soil contribute to the signature of chlorine composition in water bodies. However, little is known about the potential effects of land management activities on chlorine biogeochemistry. This study examines the effects of previous nitrogen addition on chlorine chemistry in a Pinus sylvestris (L.) forest located in south-central Sweden $\left(60^{\circ} 00^{\prime} \mathrm{N}, 13^{\circ} 43^{\prime} \mathrm{E}\right)$. Repeated addition of nitrogen to study plots over a 20 -year period resulted in total additions of 0, 450 and $900 \mathrm{~kg} \mathrm{~N} \mathrm{ha}^{-1}$. Soil samples were collected before harvesting, and soil solution and biomass were sampled following final felling.
\end{abstract}

Contrary to previous findings, we found no clear evidence that previous addition of nitrogen had hampered the formation of organic chlorine in the organic soil layer. We suggest that the effects of nitrogen addition on chlorination processes are not seen in the surface soil, but are instead manifested in the migration of organic matter in the mineral soil. Soil organic matter from the E-horizon had a lower chlorination degree in the nitrogen-amended plots than in the control plots. In addition, we observed lower $\mathrm{Cl}^{-}$levels in the seedling needles following high nitrogen fertilization $(900 \mathrm{~N})$ than in $450 \mathrm{~N}$ or control. These results add on the importance of studying chlorine dynamics with focus on what chlorinated soil organic matter can be resistant to degradation compared to average soil organic matter and what can be leached as a result of harvesting and available for vegetation. 


\section{Keywords}

Chlorine, chloride, soil, soil solution, nitrogen, forest

\section{Introduction}

Inorganic chlorine (chloride; $\mathrm{Cl}^{-}$) has been seen as an inexpensive and suitable tracer of soil and ground water solution movements (Herczeg and Leaney 2011; Hruškaa et al. 2012) and studies using $\mathrm{Cl}^{-}$as a water tracer has been a foundation for contaminant transport models (e.g. Kirchner et al. 2000). However, several studies have indicated that $\mathrm{Cl}^{-}$can be immobilized in ecosystems by different processes, including: i) ion exchange (Viers et al. 2011), ii) adsorption onto iron and aluminium oxides (Nodvin et al. 1986), iii) uptake by vegetation (Ohrui et al. 1996; White et al. 2001; Lovett et al. 2005), iv) uptake by the microbial community (Bastviken et al. 2007), v) conversion to organic forms of chlorine (e.g. Myneni 2002; Öberg 2003; Bastviken et al. 2007), and especially high chlorination rates are found in coniferous forest soils (Gustavsson et al. 2012). In addition, $\mathrm{Cl}^{-}$can be released by rock weathering from some rare types of bedrock, constituting extra input in addition to atmospheric deposition (Lovett et al. 2005). These processes may result in a net retention of $\mathrm{Cl}^{-}$in ecosystems on varying time scales when internal chlorine pools are increasing in magnitude or a net release of $\mathrm{Cl}^{-}$when internal pools are declining. Hence, it appears that soil sometimes acts as a sink for $\mathrm{Cl}^{-}$and sometimes as a source.

The conditions under which soil acts as a $\mathrm{Cl}^{-}$sink, or as a source, are not clear (Bastviken et al. 2006), although there are indications that several environmental factors may have an effect. One is the water residence time. The longer the water residence time, the longer the time for interactions with the soil, i.e. the more $\mathrm{Cl}_{\text {org }}$ 
will be formed (Bastviken et al. 2006). It has also been reported that the addition of nitrogen at amounts corresponding to forest fertilization seems to hamper the formation of organic chlorine $\left(\mathrm{Cl}_{\text {org }}\right)$ (Öberg et al. 1996; Johansson et al. 2001). In addition, forest harvesting experiments have shown that clear-cutting generally leads to increased leaching of $\mathrm{Cl}^{-}$(Kauffman et al. 2003; Lovett et al. 2005; Mannerkoski et al. 2005). Several factors related to forestry such as fertilization and harvesting is likely to have an effect on $\mathrm{Cl}^{-}$cycling as they are changing the ecosystem to a great deal, but on what level and to what extent is unknown. Since $\mathrm{Cl}^{-}$is frequently used as a tracer to determine soil solution flows, increased knowledge about chlorine transport will improve our understanding of how solutes other than chlorine move through the soil. This is of importance in fields such as hydrology, biogeochemistry, terrestrial ecology and soil remediation.

The current study investigates the influence of nitrogen on levels of inorganic and organic chlorine in soil in a Pinus sylvestris (L.) forest after repeated nitrogen addition followed by an investigation of levels of chlorine in soil solution and biomass after final felling. We hypothesize that i) the amount of chlorinated organic matter in soil will decrease with increasing fertilization intensity due to a decrease of the organic layer $\mathrm{Cl}$ pool, ii) the leachable chlorine following forest harvesting decreases with increasing $\mathrm{N}$ fertilization intensity, which also will affect the biomass pool. The increase is negatively related to the $\mathrm{Cl}: \mathrm{C}$ ratio in the organic layer.

\section{Materials and methods}

The study was conducted in an experimental forest, 165 Hagfors, in south-central Sweden $\left(60^{\circ} 00^{\prime} \mathrm{N}, 13^{\circ} 43^{\prime} \mathrm{E}\right)$, hereafter referred to as Hagfors, consisting of a $P$. 
sylvestris stand, in which the experiment was established in 1981. Further details on the Hagfors experiment can be found in Ring et al. (2011, 2013). The annual mean temperature in the area is $3.5^{\circ} \mathrm{C}$ and the annual mean precipitation is $671 \mathrm{~mm}$ (Alexandersson et al. 2001). The upper part of the sandy-silty till was podzolized. The median deposition of $\mathrm{Cl}^{-}$was $2-18 \mathrm{~kg} \mathrm{ha}^{-1}$ (1997-2010) at a station with open collectors approximately $50 \mathrm{~km}$ southwest from the experimental forest (operated by Swedish Environmental Research Institute; http://www.krondroppsnatet.ivl.se/).

The original purpose of the experiment at Hagfors was to determine stemwood growth at different fertilization intensities. Seven treatments were allocated to $30 \times 30 \mathrm{~m}^{2}$ study plots in a randomized block design with three replicates. In the present study, three of these treatments were investigated, namely 0, 450 and $900 \mathrm{~kg} \mathrm{~N} \mathrm{ha}^{-1}$ (total $\mathrm{N}$ dose applied, denoted $0 \mathrm{~N}, 450 \mathrm{~N}$ and $900 \mathrm{~N})$. In the $450 \mathrm{~N}$ treatment, $150 \mathrm{~kg} \mathrm{~N} \mathrm{ha}^{-1}$ was applied at 8 year-intervals, i.e. in 1981, 1989 and 1997. In the $900 \mathrm{~N}$ treatment, $150 \mathrm{~kg}$ $\mathrm{N} \mathrm{ha}^{-1}$ was applied at 4-year intervals, i.e. in 1981, 1985, 1989, 1993, 1997 and 2001. Nitrogen was applied as $\mathrm{NH}_{4} \mathrm{NO}_{3}$ and $1 \mathrm{~kg} \mathrm{~B} \mathrm{ha}^{-1}$ was added at each application. From 1991 onwards, dolomite was also included in the fertilizer (Ring et al. 2011).

In the spring of 2006, the $P$. sylvestris stand was harvested leaving no logging residues on the plots. In late May 2006 the plots were planted with 18-month-old $P$. sylvestris containerized seedlings at $2 \mathrm{~m}$ spacing.

\section{Soil}

Soil samples were collected before harvesting, in June of 2005. Samples were collected from the FH layer and from 0 to $20 \mathrm{~cm}$ of the mineral soil (E and Bs horizon, as described by Ring et al. (2011). From each plot; 20 sub-samples were 
collected from the FH-layer (mean soil depth for each plot varied from 34 to $48 \mathrm{~mm}$ ) and 40 sub-samples from the mineral soil (mean soil depth for each plot varied from 64 to $86 \mathrm{~mm}$ for the E-horizon and from 51 to $113 \mathrm{~mm}$ for the samples collected from the B horizon) with a soil auger. The mineral soil samples were separated to form composite samples for each E and B horizon and plot. In the present study, subsamples taken from the samples used in the study by Ring et al. (2011) were further prepared for chlorine analysis. Sampling was performed on each of the three replicate forest plots giving 27 samples in total.

The water content of the soil was determined by drying the soil to a constant weight at $105^{\circ} \mathrm{C}$. The soil was sieved using a $2-\mathrm{mm}$ mesh and then milled to $0.5 \mathrm{~mm}$. The milled soil was stored in glass bottles at room temperature until loss-on-ignition, total chlorine (TX), and total organic halogens (TOX) were analysed (see below). The samples were thoroughly mixed before the analyses were carried out. Loss on-ignition was determined by combusting the milled soil for $2 \mathrm{~h}$ at $620^{\circ} \mathrm{C}$, the amount of organic carbon being estimated to be $50 \%$ of the weight loss. One replicate was analysed per soil sample.

\section{Soil solution}

Soil solution was collected from the mineral soil at a depth of about 40 to $45 \mathrm{~cm}$, i.e. from the lower B or upper C horizon, using ceramic suction cups (type P80, CeramTec AG, Germany). Three cups per plot were installed in the forest before harvesting in May 2005. Each cup was connected to a 1-litre glass bottle through silicone tubing. A suction pressure of 75 cbar was used for sampling, generated by manual pumping. These samples were collected about eight (in the $450 \mathrm{~N}$ regime) or four (in the $900 \mathrm{~N}$ regime) years after the last $\mathrm{N}$ application. In the present study, sub- 
samples of the soil solution studied by Ring et al. (2013) were analysed regarding $\mathrm{Cl}_{\text {org }}$ concentration, from six occasions in the $450 \mathrm{~N}$ regime and 13 occasions (1-3 occasions during spring and autumn during 2006-2008) in both the $0 \mathrm{~N}$ and $900 \mathrm{~N}$ regimes. One additional sampling was undertaken in late August 2011. Results on soil solution chemistry for $\mathrm{Cl}^{-}$and other solutes before and after harvesting have been presented by Ring et al. (2013).

The concentration of $\mathrm{Cl}_{\text {org }}$ in soil solution samples was determined as adsorbable organic halogens (AOX), (EU 1996). The AOX method measures the sum of chlorine, bromine and iodine and does not distinguish between the different halogens. Since chlorine is by far the most abundant of these halogens in the soil environment (Brady et al. 2002), the mass estimates are based on the assumption that chlorine dominates in the samples. If significant amounts of other halides are present, the method will overestimate the amount of $\mathrm{Cl}_{\text {org }}$ in the samples. Briefly, 20-40 $\mathrm{ml}$ (the exact volume noted) of the soil solution sample was diluted with MilliQ water to a final volume of $100 \mathrm{ml}$ in a 300-ml Erlenmeyer flask. Activated carbon (50 mg; Euroglas), acidified nitrate solution ( $20 \mathrm{ml} ; 0.22 \mathrm{M} \mathrm{KNO}_{3}, 0.02 \mathrm{M} \mathrm{HNO}_{3}$ ), and approximately 5 drops of concentrated $\mathrm{HNO}_{3}$ (yielding $\mathrm{pH}<2$ ) were added to the flasks and the suspension was placed on a rotary shaker $(180 \mathrm{rpm})$ for $1 \mathrm{~h}$. The suspension was filtered through a $0.45-\mu \mathrm{m}$ polycarbonate filter (Euroglas), and then rinsed with an acidic nitrate solution (approximately $20 \mathrm{ml} ; 0.01 \mathrm{M} \mathrm{KNO}_{3}, 0.001 \mathrm{M} \mathrm{HNO}_{3}$ ) followed by acidified reverse osmosis water (approximately $20 \mathrm{ml}$, adjusted to $\mathrm{pH} 2$ with $\mathrm{HNO}_{3}$ ). The filter was combusted in a stream of oxygen at $1000^{\circ} \mathrm{C}$ in an AOX analyser (ECS3000; Euroglas) in which the hydrogen halides formed were determined by means of microcoulometric titration with silver ions. One replicate of each sample was 
analysed. The levels detected were clearly above the $\mathrm{Cl}_{\text {org }}$ detection limit of $1 \mathrm{~g}^{-1}$. Blanks consisting of $100 \mathrm{ml}$ of Milli-Q water, containing $<3 \mu \mathrm{g}^{-1} \mathrm{Cl}_{\text {org }}$ were analysed as controls. Further information and chemical data on $\mathrm{Cl}^{-}$, total organic carbon (TOC) and other solutes in soil solution can be found in Ring et al. (2013).

\section{Vegetation on the clearcut}

In late June 2011, five years after planting, needle samples were collected from ten randomly selected $P$. sylvestris seedlings per plot for nutrient analysis. At the same time, three randomly selected $P$. sylvestris seedlings per plot were harvested for measurements of above-ground biomass. A sample of the stem (a 10-mm-thick disc), a representative branch (according to size and number of needles) and a shoot produced during the previous year were taken from each seedling. The ground vegetation was sampled at the same time as seedling sampling. Ten replicates (area 30 $\mathrm{cm} \times 30 \mathrm{~cm}$ ) were taken at random from each plot and pooled to give one sample per plot. The seedling and ground vegetation material were dried at $70{ }^{\circ} \mathrm{C}$ to a constant weight and homogenised by grinding before analysis.

\section{$\mathrm{Cl}_{\text {org }}$ and $\mathrm{Cl}^{-}$concentrations in soil and biomass}

The principle for analysing $\mathrm{Cl}_{\mathrm{org}}$ and $\mathrm{Cl}^{-}$in soil is based on the $\mathrm{AOX}$ analysis described above, but without the addition of activated carbon. TOX in a solid sample is analysed after washing the sample with a nitrate solution to remove inorganic halides. The washing procedure is excluded when analysing the total amount of halogens (TX), and the amount of $\mathrm{Cl}^{-}$is obtained by subtracting the amount of organic halogens from the total amount of halogens, since this procedure has been shown to be more reliable than extracting the soil and analysing the extract by potentiometric titration (Johansson et al. 2001). Normally, chlorine is by far the most abundant 
halogen in environmental samples; hence, the total mass of halogens is, by tradition, calculated as the amount of chlorine, as was done in the present study.

The concentration of $\mathrm{Cl}_{\text {org }}$ in solid samples was analysed according to Asplund et al. (1994). Briefly, approximately 20-30 mg of the milled sample (the exact amount was noted) was added to an acidic nitrate solution (20 ml; $\left.0.2 \mathrm{M} \mathrm{KNO}_{3}, 0.02 \mathrm{M} \mathrm{HNO}_{3}\right)$ and shaken on a rotary shaker $(180 \mathrm{rpm})$ for at least one hour. The suspension was filtered through a $0.45-\mu \mathrm{m}$ polycarbonate filter, and the analysis then followed the AOX analysis procedure described below. One replicate of each soil and biomass sample was analysed. Blanks were analysed using the same procedure but without the addition of soil. The levels detected in all samples were clearly above the detection limit, which was approximately $1 \mu \mathrm{g} \mathrm{Cl}_{\text {org }} \mathrm{g}^{-1}$ dry weight (d.w.).

TX was determined by adding $20 \mathrm{mg}$ of sieved, milled soil $(0.12 \mathrm{~mm})$ to a small crucible followed by direct combustion in the AOX analyser. One replicate of each soil sample was analysed. Blanks were analysed by combustion of the crucibles without the addition of soil. The levels detected in all samples were clearly above the detection limit, which was approximately $1 \mu \mathrm{g} \mathrm{Cl} \mathrm{org}_{\text {og }} \mathrm{g}^{-1}$.

\section{Statistics}

The soil chemistry and biomass data were statistically analysed using the MIXED procedure in SAS ver. 9.3 (http://support.sas.com). The following mixed linear model was applied:

$$
y_{i j}=\mu+a_{i}+b_{j}+e_{i j}
$$


where $y_{i j}$ is the variable of interest, $\mu$ is the overall mean, $a_{i}$ is the fixed effect of the $\mathrm{N}$ fertilization regime $i, b_{j}$ is the fixed effect of block $j$, and $e_{i j}$ is the residual.

Adjustment for multiple comparisons was made according to the Tukey-Kramer method. Soil solution chemistry data were analysed using a mixed linear model for repeated measurements, as described by Ring et al. (2013). Statistically significant effects were defined as $p<0.05$.

\section{Results}

\section{Soil}

The dominating form of chlorine in the soil was $\mathrm{Cl}_{\text {org }}$, about $70 \%$. The concentration of $\mathrm{Cl}_{\text {org }}$ ranged from 21 to $285 \mu \mathrm{g} \mathrm{Cl}_{\text {org }} \mathrm{g}^{-1}$ soil d.w. (dry weight) and the concentration of organic carbon ranged from 12 to $440 \mathrm{mg} \mathrm{C}_{\text {org }} \mathrm{g}^{-1}$ soil d.w.

The amount of $\mathrm{Cl}_{\text {org }}$ in the surface soil layer was about eight times that in the mineral soil layer (Table 1). No differences in $\mathrm{Cl}_{\text {org }}$ concentration were found in the surface soil layer subjected to the nitrogen treatments. However, the concentration of $\mathrm{Cl}_{\text {org }}$ in the two deeper soil horizons for $900 \mathrm{~N}$ was lower than for $450 \mathrm{~N}$ and $0 \mathrm{~N}$.

In order to evaluate the fraction of chlorinated organic matter the chlorine-to-carbon $(\mathrm{Cl}: \mathrm{C})$ ratio of soil organic matter was calculated by dividing the concentration of $\mathrm{Cl}_{\text {org }}$ with concentration of total carbon in soil. It can be seen from the results in Table 1 that the chlorinated organic matter in the soil increases with increasing depth. The $\mathrm{Cl}$ :C ratio in soil from plots treated with $450 \mathrm{~kg} \mathrm{~N} \mathrm{ha}^{-1}$ was about 4 times higher in the E-horizon than in the surface layer, and increased further in the Bs horizon (Figure 1). The amount of chlorinated organic matter in the soil following the $900 \mathrm{~N}$ treatment 
also increased with soil depth, but to a lesser extent than with the $450 \mathrm{~N}$ treatment. The $\mathrm{Cl}: \mathrm{C}$ ratios in the surface layer were similar for the different $\mathrm{N}$ additions. For the control plots with no $\mathrm{N}$ addition $(0 \mathrm{~N})$, the $\mathrm{Cl}$ : $\mathrm{C}$ ratio was similar in the $\mathrm{E}$ and $\mathrm{Bs}$ horizon. 
Table 1. Concentration of $\mathrm{Cl}_{\text {org }}$ and chlorine-to-carbon $(\mathrm{Cl}: \mathrm{C})$ ratios in different soil layers, based on measurements on three plots per treatment. Bold $p$-values indicate that the $\mathrm{N}$ fertilization regime had a significant effect. (Significant differences between different $\mathrm{N}$ treatments for each soil layer are indicated by different letters).

\begin{tabular}{|c|c|c|c|c|c|c|c|c|}
\hline \multirow[t]{2}{*}{$\begin{array}{l}\text { Soil } \\
\text { layer }\end{array}$} & \multicolumn{5}{|c|}{$\begin{array}{l}C l_{\text {org }} \mu g g^{-1} \text { soil d.w. } \\
(\mathrm{n}=3) \\
\text { Median (min-max) }\end{array}$} & \multicolumn{3}{|c|}{$\begin{array}{c}\text { Cl: C ratio } \\
(\mathrm{n}=3) \\
\text { Median (min-max) }\end{array}$} \\
\hline & $p$ & $0 \mathrm{~N}$ & $450 \mathrm{~N}$ & $900 \mathrm{~N}$ & $P$ & $0 \mathrm{~N}$ & $450 \mathrm{~N}$ & $900 \mathrm{~N}$ \\
\hline FH & 0.91 & $\begin{array}{c}237 \\
(164-285)\end{array}$ & $\begin{array}{c}247 \\
(217-282)\end{array}$ & $\begin{array}{c}236 \\
(223-259)\end{array}$ & 0.98 & $\begin{array}{c}0.60 \\
(0.37-0.65)\end{array}$ & $\begin{array}{c}0.55 \\
(0.49-0.64)\end{array}$ & $\begin{array}{c}0.53 \\
(0.52-0.60)\end{array}$ \\
\hline E & 0.47 & $\begin{array}{c}31 \\
(26-40)\end{array}$ & $\begin{array}{c}28 \\
(21-32)\end{array}$ & $\begin{array}{c}26 \\
(23-29)\end{array}$ & 0.15 & $\begin{array}{c}2.43 \\
(2.14-3.30)\end{array}$ & $\begin{array}{c}2.28 \\
(1.65-2.44)\end{array}$ & $\begin{array}{c}1.48 \\
(1.36-1.70)\end{array}$ \\
\hline Bs & 0.019 & $\begin{array}{c}55^{\mathrm{a}} \\
(47-65)\end{array}$ & $\begin{array}{c}59^{a} \\
(53-66)\end{array}$ & $\begin{array}{c}38^{\mathrm{b}} \\
(37-39)\end{array}$ & $<0.001$ & $\begin{array}{c}2.40^{\mathrm{a}} \\
(2.14-2.98)\end{array}$ & $\begin{array}{c}3.20^{\mathrm{b}} \\
(2.93-3.66)\end{array}$ & $\begin{array}{c}2.27^{\mathrm{a}} \\
(2.19-2.31)\end{array}$ \\
\hline
\end{tabular}

Figure 1. Box plot showing $\mathrm{Cl}: \mathrm{C}$ ratios $\left(\mathrm{Cl}_{\text {org }}\right.$ divided by total carbon) in different soil horizons following different amounts of $\mathrm{N}$ fertilization.

\section{INSERT FIGURE 1.}

\section{Soil solution}

It can be seen from Figure 2 that the concentration of $\mathrm{Cl}_{\text {org }}$ decreased with time after harvesting. The observed concentrations after suction cup installation directly after harvesting were very high, reaching almost $1000 \mu \mathrm{g} \mathrm{l^{-1 }}$. However, these results should be treated with caution as there are some indications that measure of total organic carbon might have been affected by the installation of lysimeters (Ring et al. 2013). We therefore assume that this might also be the case for $\mathrm{Cl}_{\text {org }}$. 
Figure 2. Organic chlorine $\left(\mathrm{Cl}_{\text {org }}\right)$ in soil solution after harvesting $(\mathrm{n}=3)$. The dotted line indicates time for harvesting.

\section{INSERT FIGURE 2}

The concentration of $\mathrm{Cl}_{\text {org }}$ without fertilization (0N) was around $200 \mu \mathrm{g} \mathrm{1^{-1 }}$ already in October 2006, six months after harvesting. The mean concentration stayed fairly constant from November 2006 to September 2007 (varying between approximately 130 and $214 \mu \mathrm{g} \mathrm{l}^{-1}$ ). From October 2007, the concentration fell to approximately 80 $\mu \mathrm{g} 1^{-1}$, and dropped even more during the spring of $2008, \sim 40 \mu \mathrm{g}^{-1}$. The concentration remained low, $40 \mu \mathrm{g} 1^{-1}$, in samples collected in August 2011, five years after harvesting.

Similar patterns were seen for the other treatments, but with some differences (Figure 2). For instance, the concentration of $\mathrm{Cl}_{\text {org }}$ in plots treated with $900 \mathrm{~N}$ was similar to that in control plots during the autumn of 2006, but during the following spring in 2007 (one year after harvesting) the soil solution concentration of $\mathrm{Cl}_{\text {org }}$ in these fertilized forest plots was half the concentration found in control plots. Soil solution from $450 \mathrm{~N}$ showed relative high $\mathrm{Cl}_{\text {org }}$ concentrations during the first months after harvesting. In 2008 , the concentrations in the $450 \mathrm{~N}$ plots were similar to concentrations in the $0 \mathrm{~N}$ and $900 \mathrm{~N}$ plots. No statistically significant differences could be seen for the different $\mathrm{N}$ treatments over the whole sampling period $(p=0.17)$.

The $\mathrm{Cl}$ :C ratios in the soil solution decreased with time after harvesting in all forest plots (Figure 3). The ratios ranged from 35 to $160 \mathrm{mg} \mathrm{Cl} \mathrm{g} \mathrm{C}^{-1}$ during 2006 and 2007, and decreased to below $40 \mathrm{mg} \mathrm{Cl} \mathrm{g} \mathrm{C}{ }^{-1}$ during 2008. During spring 2007, the $\mathrm{Cl}: \mathrm{C}$ ratios were lower in $\mathrm{N}$-fertilized plots $(900 \mathrm{~N})$ than in the control plots, while in 2008 
and thereafter the ratios were similar. No statistically significant differences were seen between the different $\mathrm{N}$ treatments for the whole period $(p=0.70)$.

Fig. 3. Median chlorine-to-carbon ratio $\left(\mathrm{mg} \mathrm{Cl} \mathrm{g} \mathrm{C}^{-1}\right)$ in soil solution after harvesting $(n=3)$.

\section{INSERT FIGURE 3}

\section{Vegetation biomass}

The concentrations of $\mathrm{Cl}^{-}$ranged from 37 to $372 \mu \mathrm{g} \mathrm{g}^{-1}$ d.w. (median: $97 \mu \mathrm{g} \mathrm{g}^{-1}$ d.w.) for seedling biomass and ground vegetation (Table 2). Needles and ground vegetation had the highest $\mathrm{Cl}^{-}$concentrations (11-372 $\mu \mathrm{g} \mathrm{g}{ }^{-1}$ d.w.). The lowest $\mathrm{Cl}^{-}$concentrations were found in stems (2-4 times lower than in needles), while the values in branches were slightly higher.

All parts of the biomass investigated had a low content of $\mathrm{Cl}_{\text {org }}$ relative to $\mathrm{Cl}^{-}$, where $\mathrm{Cl}_{\text {org }}$ varied from 1 to $48 \mu \mathrm{g} \mathrm{g}^{-1}$ d.w. (median: $6 \mu \mathrm{g} \mathrm{g}^{-1}$ d.w.). Contrary to $\mathrm{Cl}^{-}$, similar $\mathrm{Cl}_{\text {org }}$ concentrations were found in the investigated biomass. The percentage $\mathrm{Cl}_{\text {org }}$ of total chlorine in biomass averaged $9 \%$.

\section{Effects of $N$ regime}

The $\mathrm{Cl}^{-}$concentrations in needles were lower in the plots with the most intensive fertilization regime $(900 \mathrm{~N})$ (Table 2), and the effect of $\mathrm{N}$ regime was significant $(p=0.01)$. The $\mathrm{Cl}$ : $\mathrm{C}$ ratio ranged from $<0.01$ to $0.94 \mathrm{mg} \mathrm{g}^{-1}$ among stem, needles and branches. We found no significant effects of $\mathrm{N}$ regime on the $\mathrm{Cl}^{-}$concentrations or $\mathrm{Cl}: \mathrm{C}$ ratios in stems, branches or ground vegetation. In addition, we found no correlations between either $\mathrm{Cl}^{-}$to $\mathrm{N}$ or $\mathrm{C}$ content or $\mathrm{Cl}_{\text {org }}$ to the same. 
Table 2. Concentrations of organic chlorine $\left(\mathrm{Cl}_{\text {org }}\right)$ and $\mathrm{Cl}^{-}$in stems, branches and needles from $P$. sylvestris seedlings sampled five growing seasons following harvesting. Ground vegetation was sampled at the same time as the seedlings.

\begin{tabular}{|c|c|c|c|c|c|c|c|c|}
\hline \multirow[t]{2}{*}{ Biomass } & \multicolumn{5}{|c|}{$\begin{array}{c}C l \mu g g^{-1} \text { d.w. } \\
\qquad(\mathrm{n}=3) \\
\text { Median (min-max) }\end{array}$} & \multicolumn{3}{|c|}{$\begin{array}{c}C l_{\text {org }} \mu g g^{-1} \text { d.w. } \\
\qquad(\mathrm{n}=3) \\
\text { Median (min-max) }\end{array}$} \\
\hline & $p$ & $0 \mathrm{~N}$ & $450 \mathrm{~N}$ & $900 \mathrm{~N}$ & $P$ & $0 \mathrm{~N}$ & $450 \mathrm{~N}$ & $900 \mathrm{~N}$ \\
\hline Stem & 0.15 & $\begin{array}{c}64.6 \\
(45.0-93.5)\end{array}$ & $\begin{array}{c}80.1 \\
(66.6-97.4)\end{array}$ & $\begin{array}{c}54.0 \\
(37.2-60.3)\end{array}$ & 0.84 & $\begin{array}{c}12.4 \\
(6.1-28.4)\end{array}$ & $\begin{array}{c}6.0 \\
(3.1-48.2)\end{array}$ & $\begin{array}{c}11.5 \\
(8.5-11.7)\end{array}$ \\
\hline Branches & 0.92 & $\begin{array}{c}78.9 \\
(63.0-188.8)\end{array}$ & $\begin{array}{c}102.4 \\
(57.7-179.4)\end{array}$ & $\begin{array}{c}107.3 \\
(88.1-107.6)\end{array}$ & 0.63 & $\begin{array}{c}4.9 \\
(3.1-23.2)\end{array}$ & $\begin{array}{c}4.5 \\
(4.1-12.8)\end{array}$ & $\begin{array}{c}3.0 \\
(2.4-7.9)\end{array}$ \\
\hline Needles & 0.013 & $\begin{array}{c}214.6^{\mathrm{a}} \\
(201.9-227.2)\end{array}$ & $\begin{array}{c}233.3^{\mathrm{a}} \\
(203.3-241.0)\end{array}$ & $\begin{array}{c}132.6^{\mathrm{b}} \\
(118.2-139.9)\end{array}$ & 0.58 & $\begin{array}{c}3.9 \\
(3.4-6.1)\end{array}$ & $\begin{array}{c}3.6 \\
(1.2-5.2)\end{array}$ & $\begin{array}{c}3.9 \\
(2.7-19.6)\end{array}$ \\
\hline $\begin{array}{l}\text { Ground } \\
\text { vegetation }\end{array}$ & 0.31 & $\begin{array}{c}134.3 \\
(111.9-162.9)\end{array}$ & $\begin{array}{c}203.6 \\
(185.0-372.9)\end{array}$ & $\begin{array}{c}135.4 \\
(121.8-257.7)\end{array}$ & 0.73 & $\begin{array}{c}14.9 \\
(8.7-29.5)\end{array}$ & $\begin{array}{c}18.9 \\
(12.2-23.4)\end{array}$ & $\begin{array}{c}14.7 \\
(13.2-16.7)\end{array}$ \\
\hline
\end{tabular}

\section{Discussion}

No observable effects of $N$ amendment on chlorine content in top-soil

Not surprisingly, adding nitrogen to forest soil can significantly affect the

biogeochemical cycling of, for instance, soil organic matter (e.g. Hyvönen et al.

2008). This is of concern for chlorine cycling as it appears that the chlorination of

organic matter is related to both amount of soil organic matter and the type of

vegetation (Gustavsson et al. 2012). Most of the studies on chlorine biogeochemistry have been performed on the organic-rich surface soil layer. Our hypothesis was that the $\mathrm{Cl}_{\text {org }}$ concentration would decrease with intensified nitrogen fertilization as has been the observed in previous studies (Johansson et al. 2001, Öberg et al. 1996). In 
the present study, we did not observe any effects on the long-term of nitrogen amendment on chlorine content in the organic top-soil.

One of the previous studies on the effect of nitrogen on chlorine content in soil showed decreasing concentrations of $\mathrm{Cl}_{\text {org }}$ in soil with increasing $\mathrm{N}$ amendment (Johansson et al. 2001). The lab-incubated soil was sampled from the organic-rich surface soil layer, and the concentration of $\mathrm{Cl}_{\text {org }}$ and the $\mathrm{Cl}: \mathrm{C}$ ratio in soil were similar to those found in the present study. Johansson et al. (2001) suggest that the decrease in $\mathrm{Cl}_{\text {org }}$ concentration is a direct microbial response to $\mathrm{N}$ amendment, a hampered microbial chlorination of organic matter. The results from the laboratory incubation study probably reflect a short-term response relatively to the current study because the measuring was done within less than two months, compared to the current study that was done under field conditions and on another time scale (years $v s$ months).

Opposite to the surface soil, we observed differences in chlorine content in the lower soil layers for control plots and the $\mathrm{N}$ amended plots. In the $\mathrm{E}$ horizon, the most intensive $\mathrm{N}$ fertilization regime $(900 \mathrm{~N})$ led to a lower concentration of $\mathrm{Cl}_{\text {org }}$ than in the control plots $(0 \mathrm{~N})$. In the Bs horizon, amendment with $450 \mathrm{~kg} \mathrm{~N}$ led to higher $\mathrm{Cl}: \mathrm{C}$ ratios than in control plots and in plots amended with $900 \mathrm{~kg} \mathrm{~N}$, which showed similar ratios to those in the control plots. As the sampling in the current study was done more than five years after the last addition of nitrogen, one explanation could be that a chlorination processes that was taken place in the surface soil would, after this time, be seen in the deeper soil horizons.

In all soil samples, we observed higher $\mathrm{Cl}: \mathrm{C}$ ratio in the deeper soil layers than in the surface soil layer. Previous studies have emphasized that the migration of soil organic 
matter through different soil layers is important for internal $\mathrm{Cl}$ cycling in soils (e.g. Öberg and Sandén 2005). Migration of chlorinated organic matter in soils is relatively new finding and few researchers have tried to determine the $\mathrm{Cl}_{\text {org }}$ content in different types of soil organic matter. Bastviken et al. (2007 and 2009) found that $1-10 \%$ of the $\mathrm{Cl}_{\text {org }}$ in coniferous soil was associated with the water-leachable fraction of organic matter. Beside formation of $\mathrm{Cl}_{\text {org }}$ in soil, Leri and Myneni (2010) suggest that plant litter $\mathrm{Cl}_{\text {org }}$ contributes to both the water soluble fraction and recalcitrant organic matter. Very little is known about the type of chlorinated organic material that is leached down the soil profile, accumulated and what time it takes.

\section{Chlorinated organic matter in soil solution}

The observed soil solution concentrations in the forest plots studied here were generally lower than $200 \mu \mathrm{g} \mathrm{l}^{-1}$, and only in a few cases below $40 \mu \mathrm{g} \mathrm{l}^{-1}$. To the best of our knowledge, only one previous field study has been performed on $\mathrm{Cl}_{\text {org }}$ concentrations in soil solution. Öberg and Grön (1998) analysed the soil solution at a soil depth of 45-50 cm, similar to our study, and found median concentrations of 185 $\mu \mathrm{g} \mathrm{l}^{-1}\left(70-250 \mu \mathrm{g} \mathrm{l}^{-1}\right)$, which is similar to the current study. Higher $\mathrm{Cl}_{\mathrm{org}}$ concentrations, a median of $400 \mu \mathrm{g} \mathrm{l}^{-1},\left(250-1000 \mu \mathrm{g}^{-1}\right)$ were observed in a laboratory soil lysimeter study by Rodstedth et al. (2003). However, the values in the laboratory study were obtained by leaching a $15 \mathrm{~cm}$ soil core, i.e. the surface soil, which contains more $\mathrm{Cl}_{\text {org }}$ than deeper soil layers. The most surprising results of the present study are the relatively high $\mathrm{Cl}: \mathrm{C}$ ratios in soil solution, which varied from 35 to $160 \mathrm{mg} \mathrm{Cl} \mathrm{g} \mathrm{C}^{-1}$ in soil solution. These ratios are much higher than the $\mathrm{Cl}: \mathrm{C}$ ratios in soil core leachates (3.1-8.5 $\mathrm{mg} \mathrm{Cl} \mathrm{g} \mathrm{C}^{-1}$ ) observed by Rodhstedt et al. (2003). In addition, the $\mathrm{Cl}: \mathrm{C}$ ratios in bulk soil of the present study, irrespective soil horizon or 
degree of $\mathrm{N}$ fertilization, were only 0.4 to $3.7 \mathrm{mg} \mathrm{Cl} \mathrm{g} \mathrm{C}^{-1}$ in soil) which indicate a fraction of mobile chlorinated organic matter in soil. However this comparison should be treated with caution as the soil bulk sampling was done before harvest and the soil solution sampling after harvesting. Öberg and Sandén (2005) also found higher $\mathrm{Cl}: \mathrm{C}$ ratios in soil leachate from $15-\mathrm{cm}$-deep soil cores than in bulk soil. Despite that, $\mathrm{Cl}: \mathrm{C}$ ratios in soil leachate were general less than $10 \mathrm{mg} \mathrm{Cl} \mathrm{g} \mathrm{C}^{-1}$ in the study by Öberg and Sandén (2005), which is much less than the current study. The knowledge on chlorination and transport and migration of chlorinated organic material through the soil is small, which make the interpretation of $\mathrm{N}$ effect difficult. If looking over the whole observation period, we cannot see a clear pattern of the influence of fertilization when we compare soil solution from the different $\mathrm{N}$ treatments, i.e. a decreased leaching of chlorine with increasing fertilization intensity. The chlorine soil dynamics are related to various factors besides the fertilization. One major factor is hydrology. For instance, the washout of organic matter is usually greater during spring and snow melt. The more mobile the soil organic matter, the more organic matter will leach down the soil layers. In combination with present chlorination hypotheses; chlorination of organic matter could make the organic matter more water leachable and/or a preference for chlorination of easy degradable organic matter (Leri and Myneni 2010, Öberg and Sandén 2005). During the first spring after harvesting, in 2007, we observed lower $\mathrm{Cl}$ :C ratios in soil solution from nitrogen-fertilized plots (however not significant for the whole period). One may hypothesize that the lower $\mathrm{Cl}$ : $\mathrm{C}$ ratios in soil solutions in $\mathrm{N}$ amended plots are due to lower chlorination rates in fertilized soil, i.e. $\mathrm{N}$ fertilization has hampered the chlorination of organic matter leading to less chlorinated organic matter in deeper soil layers. These observation 
needs to be further investigated by looking into e.g. how chlorine dynamics (changes in surface soil and migration of chlorinated organic matter) are affected by $\mathrm{N}$ amendment in soil profiles.

\section{Cl in biomass}

The $\mathrm{Cl}^{-}$content of plant biomass varies between plant species (Lobert et al 1999). A general requirement of $1 \mathrm{mg} \mathrm{Cl}^{-} \mathrm{g}^{-1} \mathrm{~d}$.w. has been suggested, but $\mathrm{Cl}$ deficiency has been observed at 0.1-5.7 $\mathrm{mg} \mathrm{Cl}^{-} \mathrm{g}^{-1} \mathrm{~d} . \mathrm{w}$., and toxic levels between 4 and $50 \mathrm{mg} \mathrm{g}^{-1}$ d.w. have been reported (White et al. 2001). The observed lower $\mathrm{Cl}^{-}$levels in the seedling needles following high nitrogen fertilization $(900 \mathrm{~N})$ than in $450 \mathrm{~N}$ or control, could indicate $\mathrm{Cl}^{-}$stress. Previous nitrogen addition had no effects on seedling growth and vegetation biomass in the present study, which might support a hampered growth in $\mathrm{N}$ amended plots, despite more available nutrients (Johansson et al. forthcoming). In addition, the large range in the observed levels of $\mathrm{Cl}^{-}$means that extrapolation across species and location are highly unreliable. The plant $\mathrm{Cl}_{\text {org }}$ content has previously been estimated to be $0.01-0.1 \mathrm{mg} \mathrm{g}^{-1} \mathrm{~d}$.w. (Öberg et al. 2005), but this is based on scattered measurements from beech leaves, spruce needles, sphagnum moss and bulk samples of grass, and the variability between species and plant parts is not known. The concentrations of $\mathrm{Cl}_{\text {org }}$ in the current study are in the lower range of previous studies, with a maximal concentration of $0.04 \mathrm{mg} \mathrm{g}^{-1} \mathrm{~d} . \mathrm{w}$.

There is little knowledge on what may influence the pool of available $\mathrm{Cl}^{-}$to vegetation and also the $\mathrm{Cl}$ cycling dynamics in soil and vegetation. The reasons for the high $\mathrm{Cl}: \mathrm{C}$ ratios and decrease of $\mathrm{Cl}^{-}$in soils will remain puzzling and challenge conventional knowledge. Ring et al. (2013) observed a decrease of $\mathrm{Cl}^{-}$in soil solution 
throughout the study period. The observed $\mathrm{Cl}^{-}$concentrations decreased over time, and at the end of the study was about $20 \%$ of the concentration measured soon after harvesting. The final $\mathrm{Cl}^{-}$concentration measured, five years after harvesting was about $0.9 \mathrm{mg} \mathrm{L}^{-1}$, which is similar to rain concentrations. $\mathrm{Cl}^{-}$accounted for about $80 \%$ of the total amount of chlorine in soil solution directly after harvesting, and five years after harvesting increased to approximately $95 \%$. Thereby the available $\mathrm{Cl}^{-}$decreased dramatically over time, which may have had implications for the vegetation. The annual root uptake of $\mathrm{Cl}^{-}$by Scots Pine (Pinus sylvestris) was found to be 9-fold larger than $\mathrm{Cl}^{-}$demand by the tree and the excess $\mathrm{Cl}^{-}$was returned primarily as $\mathrm{Cl}^{-}$in throughfall and to some extent by litterfall (van den Hoof and Thiry 2012). There are however no differences in $\mathrm{Cl}^{-}$concentrations in soil solution in the different $\mathrm{N}$ treatment plots, which could explain the lower $\mathrm{Cl}^{-}$levels in seedling needles for $900 \mathrm{~N}$ treatment.

\section{No chloride pulse?}

The export of $\mathrm{Cl}^{-}$from soil via groundwater to surface water has been considered to be primarily controlled by $\mathrm{Cl}^{-}$input through precipitation and, therefore, it has been assumed in many studies to be largely inert in ecosystems, with little uptake or release by vegetation or soils (Schlesinger 1997). Previous forest harvesting experiments have shown that clear-cutting generally leads to an increase in the leaching of $\mathrm{Cl}^{-}$(Likens et al. 1970; Kauffman et al. 2003; Lovett et al. 2005). These observations strongly indicate that there is a $\mathrm{Cl}^{-}$source in soil, and the $\mathrm{Cl}^{-}$does not act as a conservative element.

A disturbance such as harvesting is likely to lead to increased mineralization of organic matter, which may lead to an increased release of $\mathrm{Cl}^{-}$previously bound to the 
organic matter, producing a peak in $\mathrm{Cl}^{-}$concentration in soil solution after harvesting. In this forest experiment, the $\mathrm{Cl}^{-}$concentration in soil solution decreased steadily after harvesting for all treatment plots (data not shown). Forest management has considerable impact on the forest ecosystem, in particular the hydrology and vegetation composition. However, due to the lack of data before harvesting we cannot elucidate if there was a chloride pulse. The chlorine dynamics in forest systems are most likely influenced by e.g. forest harvesting, which causes increased organic matter decomposition rates, but also changes vegetation composition, and reduces dry deposition (throughfall) and litterfall due to canopy removal. During the field study period, we observed a decrease in $\mathrm{Cl}_{\text {org }}$ concentrations in soil solution with time after harvesting. It is likely to believe that reduced evapotranspiration caused by tree removal can result in dilution of soil organic matter, which was concluded by the observation of simultaneously decrease in $\mathrm{Cl}: \mathrm{C}$ ratio. However, the evapotranspiration after harvest was probably not progressively reduced over the observation years and can therefore not explain the decreasing trend over several years.

\section{Conclusions}

Contrary to previous findings, fertilization with nitrogen amendment had no observable effect on chlorine content in the top-soil. We suggest that the effects of nitrogen addition on chlorine content in soil are caused by chlorination processes that are not sustained in the surface soil, but rather seen in the migration of organic matter in the mineral soil. This is in line with previous studies on chlorine biogeochemistry, in which it was emphasized that the migration of soil organic matter across different depth zones is important for internal $\mathrm{Cl}$ cycling in soils. The soil organic matter in the E-horizon showed a lower $\mathrm{Cl}: \mathrm{C}$ ratio in the nitrogen-amended plots than in the control 
plots, and the organic matter in soil solution also showed lower ratios in nitrogenamended plots during the first spring season after harvesting. These results underline the importance of studying soil chlorine dynamics in order to determine which fraction is resistant to degradation and thus selectively preserved, and which fraction is leached in relation to nitrogen fertilization and final felling.

\section{Acknowledgements}

The authors thank the land owner, Bergvik and Stora Enso, for hosting the experiment, and for adapting their procedures to accommodate the experimental design. We wish to thank Lars-Åke Dahl, Thomas Hjerpe, Hagos Lundström, Sten Nordlund and Ove Nyberg for valuable field work. The study was partly financed by grants from The Swedish Research Council for Environment, Agricultural Sciences and Spatial Planning. Teresia Svensson also thanks Knut and Alice Wallenberg's Foundation for travel stipend. We would like to thank Monica Petersson and the students Maria Fredriksson, Karin Fredriksson, Emilia Karlsson, Viktor Lundborg, Isabella Nyiri and David Törngren for much appreciated assistance in sample analysis. Finally we would like to thank the anonymous referees for constructive comments. 


\section{References}

Alexandersson H. and Eggertsson Karlström D. (2001). Temperaturen och nederbörden i Sverige 1961-1990. Referensnormaler - utgåva 2. SMHI Meteorologi $\mathrm{Nr}$ 99. Swedish Meteorological and Hydrological Institute.

Asplund G, Grimvall A, Jonsson S. (1994). Determination of the total and leachable amounts of organohalogens in soil. Chemosphere 28: 1467-1475.

Bastviken D, Sandén P, Svensson T, Ståhlberg C, Magounakis M, Öberg G. (2006). Chloride retention and release in a boreal forest soil - effects of soil water residence time and nitrogen and chloride loads. Environmental Science and Technology 40: 2977-2982.

Bastviken D, Thomsen F, Svensson T, Karlsson S, Sandén P, Shaw G, Matucha M, Öberg G. (2007). Chloride retention in forest soil by microbial uptake and by natural chlorination of organic matter. Geochimica et Cosmochimica Acta 71: 3182-3192.

Bastviken D, Svensson T, Karlsson S, Sandén P, Öberg G. (2009). Temperature sensitivity indicates that chlorination of organic matter in forest soil is primarily biotic. Environmental Science and Technology. 43: 3569-3573.

Brady N, Weil R. (2002). The nature and properties of soils. New Jersey, Pearson Education Inc.

EU (1996). Water Quality - Determination of adsorbable organically bound halogens (AOX). Approved April 1996:1485.

Gustavsson M, Karlsson S, Öberg G, Sanden P, Svensson T, Valinia S, Thiry Y, Bastviken D. (2012). Organic matter chlorination rates in different boreal soils: the role of soil organic matter content. Environmental Science and Technology 46: 1504-1510.

Herczeg AL, Leaney F. (2011). Review: Environmental tracers in arid-zone hydrology. Hydrogeology Journal. 19: 17-29.

Hruškaa J, Oulehlea F, Šamonilc P, Šebestad J, Tahovskáe K, Hlebd R, Houškad J, Šikla J. (2012). Long-term forest soil acidification, nutrient leaching and vegetation development: Linking modelling and surveys of a primeval spruce forest in the Ukrainian Transcarpathian Mts. Ecological modeling. 244: 28-37.

Hyvönen R, Persson T, Andersson S, Olsson B, Ågren GI, Linder S. (2008) Impact of long-term nitrogen addition on carbon stocks in trees and soils in northern Europe. Biogeochemistry. 89: 121-137.

Johansson E, Ebenå G, Sandén P, Svensson T, Öberg G. (2001). Organic and inorganic chlorine in Swedish spruce forest soil: influence of nitrogen. Geoderma 101: 1-13.

Kauffman S, Royer D, Chang S, Berner R. (2003). Export of chloride after clearcutting in the Hubbard Brook sandbox experiment. Biogeochemistry 63: 23-33.

Kirchner JW, Feng X, Neal C, (2000). Fractal stream chemistry and its implications for contaminant transport in catchments. Nature. 403: 524-527.

Leri AC, Myneni SCB, (2010). Organochlorine turnover in forest ecosystems: The missing link in the terrestrial chlorine cycle. Global Biogeochemical Cycles 24 . GB 4021. doi:10.1029/2010GB003882.

Likens G, Bormann F, Johnson N, Fisher D, Pierce R. (1970). Effects of forest cutting and herbicide treatment on nutrient budgets in the Hubbard Brook watershedecosystem. Ecological Monographs 40:23-47. 
Lobert JM, Keene WC, Logan JA. Yevich R. (1999). Global chlorine emissions from biomass burning: reactive chlorine emissions inventory. Journal of Geophysical Research 104: 8373-8389.

Lovett GM, Likens GE, Buso DC, Driscoll CT, Bailey SW. (2005). The biogeochemistry of chlorine at Hubbard Brook, New Hampshire, USA. Biogeochemistry 72: 191 - 232

Mannerkoski H, Finér L, Piirainen S, Starr M. (2005). Effect of clear-cutting and site preparation on the level and quality of groundwater in some headwater catchments in eastern Finland. Forest Ecology and Management 220: 107-117

Myneni S. (2002). Formation of stable chlorinated hydrocarbons in weathering plant material. Science 295: 1039-1041.

Nodvin SC, Driscoll CT, Likens GE. (1986). Simple partitioning of anions and dissolved organic-carbon in a forest soil. Soil Science 142: 27-35.

Öberg G, Nordlund E, Berg B. (1996). In situ formation of organically bound halogens during decomposition of Norway spruce needles: effect of fertilization. Canadian Journal of Forest Research 26: 1040-1048.

Öberg G. Grön C. (1998). Sources of organic halogens in a Danish spruce forest soil. Environmental Science and Technology 32: 1573-1579.

Öberg G. (2003). The biogeochemistry of chlorine in soil. The Handbook of Environmental Chemistry. The Natural Production of Organohalogen Compounds. G. Gribble, Springer-Verlag.

Öberg G, Holm M, Sandén P, Svensson T, Parikka M. (2005). The role of organicmatter-bound chlorine in the chlorine cycle: a case study of the Stubbetorp catchment, Sweden. Biogeochemistry 75: 241-269.

Öberg G, Sandén P. (2005). Retention of chloride in soil and cycling of organic matter-bound chlorine. Hydrological Processes 19: 2123-2136

Ohrui K. Mitchell MJ. (1996). Elemental dynamics of a Japanese watershed with sugi (Cryptomeria japonica) and hinoki (Chamaecyparis obtusa) plantations. Canadian Journal of Forest Research 26: 2160-2169.

Ring E, Jacobson S, Högbom L. (2011). Long-term effects of nitrogen fertilization on soil chemistry in three Scots pine stands in Sweden. Canadian Journal of Forest Research 41: 279-288.

Ring E, Högbom L, and Jansson G. (2013) Effects of previous nitrogen fertilization on soil-solution chemistry after final felling and soil scarification at two nitrogen-limited forest sites. Canadian Journal of Forest Research 43: 396-404

Rodstedth M, Ståhlberg C, Sandén P, Öberg G. (2003). Chloride imbalances in soil lysimeters. Chemosphere 52: 381-389.

Schlesinger W. (1997). Biogeochemistry. An analysis of global change. San Diego, Academic Press.

Viers J, Dupre B, Braun J, Freydier R, Greenberg S, Ngoupayou JN, Nkamdjou L. (2001). Evidence for non-conservative behaviuor of chlorine in humid tropical environments. Aquatic Geochemistry 7: 127-154.

White P. Broadley M. (2001). Chloride in soils and its uptake and movement within the plant: A review. Annals of Botany 88: 967-988. 